Kleine was seconded for service with the German Sleeping Sickness Expedition in East Africa under Koch's leadership. His particular researches related to preventive measures against the disease. Later he returned to East Africa as leader of a campaign against sleeping sickness. On this visit he made the important discovery that the trypanosome causing the disease is not carried from the sick to the healthy by the tsetse fly in a direct mechanical way, as had been believed, but undergoes a fairly prolonged cycle of development in the fly after the fly has fed on infected blood. This discovery by Kleine opened a new road to investigators, and led to many advances in knowledge of the epidemiology of trypanosome diseases.

After an interruption to research caused by the First World War, Kleine was granted permission in 1921 to visit Northern Rhodesia and the Belgian Congo to test a new drug, 'Bayer 205' ('germanin'), in human and animal trypanosomiasis. In 1926 he was nominated as the German delegate on the League of Nations International Commission on Human Trypanosomiasis, and, working in Uganda, Kenya and Tanganyika, he investigated problems of immunity against trypanosomes in natives living in chronic foci of sleeping sickness.

In 1933 Kleine was elected president of the Robert Koch Institute in Berlin, where he continued his researches on relapsing fever, foot-and-mouth disease, rinderpest, trypanosomiasis and other tropical and veterinary diseases, revisiting Southern Rhodesia and East Africa during 1934-35, and South Africa during 1936-37. In 1947 he retired to South Africa, where he spent the last days of his life.

Kleine's patent honesty, his conscientiousness in research, his sense of humour, and unvarying courtesy won for him many friends among his colleagues and British co-workers in Africa. He married Hanna Ockelmann, who accompanied him on his many journeys and assisted him in his scientific work during the last thirty years of his life, and who survives him. They had one son, who was killed in Bucharest in the Second World War.

$$
\text { R. L. ShEPPARD }
$$

\section{Mr. A. S. E. Ackermann}

Mr. A. S. E. Ackermann died at the age of eighty-three on April 7. He practised as a consulting engineer in Westminster and his work covered a wide range.

Though born in London, Ackermann received his first training at the South African College, now the University of Cape Town. Later, in London, he was one of the early students at the City and Guilds College, where, after gaining his associateship in civil and mechanical engineering, he was employed by Prof. W. C. Unwin as his assistant, and many years later was elected a Fellow of the College.

Ackermann made good use of his scientific training and was always an ardent advocate of adequate qualification for all practising in any branch of science. He took the degree of B.Se.(Eng.) and later served as deputy chairman of Convocation of the University of London, after having been for eleven years honorary general secretary of the London Graduates Association. He was secretary of the Society of Engineers for more than thirty years, and for several years was the honorary general secretary of the British Section of the International Association of Journalists.
In the many branches of engineering in which he worked and gave advice, Ackermann's approach was always scientific and logical, and for that reason he was an extremely good expert witness and was successful in cases relating to noise and smoke nuisance and in 'ancient lights' disputes. He believed that it was possible to do effective practical research without the use of complex apparatus, and gave proof of this in 1919 when he did pioneer work investigating the physical properties of clay, using only household appliances. The results were given in three papers published by the Society of Engineers, in which he established a critical point which he called 'the pressure of fluidity'.

In about 1907 Ackermann became interested in the development of power from solar energy, and as engineer to a syndicate he was responsible for the designs and experiments made with several plants. The first of these was tested in America, and the final plant, which was tested in Egypt, was more elaborate; by using focusing mirrors, it produced steam at a low pressure, which was supplied to a specially designed engine. A full description of this test, together with particulars of all earlier attempts to develop solar energy, was given in a paper by Ackermann published by the Society of Engineers in 1914.

The examination of commonly accepted statements which could be checked and refuted on a scientific basis attracted Ackermann, and the collection of such cases became an absorbing interest to him. In 1907 he published a collection of these cases under the title "Popular Fallacies", which proved very suc. cessful. He continued to collect fallacies in ever widening fields, and in the fourth edition of this work, published in 1950, no less than two thousand are treated and classified under twentyseven headings.

Ackermann was a familiar figure at the meetings of numerous engineering and scientific societies and will be missed by many. He married in 1901, and his widow and two daughters survive him.

$$
\text { J. S. WILSON }
$$

$$
\text { Dr. H. J. Finlay }
$$

MicRopaLAfontology in New Zealand has suffered a serious loss in the sudden death of Dr. Harold John Finlay at his home in Karori, Wellington, on April 7. Born at Cronilla, India, in 1901, Finlay went with his parents to Dunedin, New Zealand, within a few years. He received his primary and secondary education at the Normal School there, and, after a brilliant career at the University of Otago, graduated M.Sc. in 1921 with first-class honours in chemistry. For two years, as John Edmond Fellow, he did postgraduate work in chemistry, and for the next three years was National Research Scholar in palæontology under Prof. W. N. Benson. For the following three years he was biologist to the Fisheries Branch of the Marine Department.

During the period 1923-31, Finlay published about thirty papers on molluscan systematics, mostly in the Transactions of the New Zealand Institute (later, T'rans. Roy. Soc. N.Z.) but some in the Proceedings of the Malacological Society of London. In 1926 he was awarded the Hamilton Prize for his published work, and in the following year he obtained his D.Sc. with an outstanding "Further Commentary on N.Z. Molluscan Systematics" (Trans. N.Z. Inst., 57, 320). Other important papers are, "New Shells from N.Z. 
Tertiary Beds, Parts 1-3" (Trans. N.Z. Inst., 55; 56 ; 61); and "Recent Mollusca of the Chatham Islands" (T rans. N.Z. Inst., 59).

During 1933 and 1934, as part of its oil prospecting work, Taranaki Oilfields and Vacuum Oil Co. employed Finlay to take up a study of the Cretaceous and Tertiary Foraminifera. In this new field his keen mind and ability for intense application, together with his schooling in molluscan systematics, soon produced highly significant stratigraphical results. In 1937 he was appointed micropalæontologist to the N.Z. Geological Survey, and in the next ten years he revolutionized the status of Foraminifera in the stratigraphy of New Zealand with the following papers: "New Zealand Foraminifera: Key Species in Stratigraphy, Nos. 1-5" (Trans. Roy. Soc. N.Z.,
68; 69 ; and N.Z. J. Sci. Tech., 28); "The Foraminiferal Evidence for Tertiary Trans-Tasman Correlation" (Trans. Roy. Soc. N.Z., 76) ; and, with J. Marwick, "The Divisions of the Upper Cretaceous and Tertiary in New Zealand" (Trans. Roy. Soc. N.Z., 70).

Finlay was elected Fellow of the Royal Society of New Zealand in 1939, and received from the Society the Hector Medal and Award in 1941.

In addition to his scientific activities, Finlay was an accomplished musician, in later years devoting considerable time to serious composition. A prelude and fugue of his was publicly performed and broadcast by the New Zealand National Orchestra, and some chamber music trios have been broadcast by instrumental groups.
J. MaRWICK

\section{NEWS and VIEWS}

\section{Symons Memorial Medal: Sir Geoffrey Taylor, F.R.S.}

The Symons Memorial Medal of the Royal Meteorological Society, which is awarded biennially for distinguished work in meteorological science, has been conferred this year on Sir Geoffrey Taylor in recognition of his classical work on atmospheric turbulence. Sir Geoffrey's first contribution to the subject arose from his participation as meteorologist in the Scotia Expedition to the Grand Bank of Newfoundland in 1913. This expedition followed the loss of the Titanic from collision with an iceberg in foggy weather in the Atlantic, and his work was concerned with the modification of temperature and humidity in an air mass by turbulence as it passed out to sea from a continental area or over a progressively colder sea-Grand Bank fog is commonly produced in the warm moist south-easterly air stream which encounters a very high gradient of surface temperature in the ice-chilled waters of the Grand Bank area. He made kite observations from the Scotia and was able to interpret them in terms of a theory of turbulence which effectively anticipated Prandtl's mixing-length theory of turbulence. Later papers followed in the Proceedings and Philosophical Transactions of the Royal Society, dealing with momentum transfer by turbulence, the drag of the earth on the wind and the variation of wind with height in the planetary boundary layer. In 1917 Sir Geoffrey gave a very full discussion of the problem of the formation of fog over land as well as at sea, and devised a fog-prediction diagram for Kew Observatory, using methods which have since been elaborated by others. Later he designed a very simple but elegant bi-directional vane for recording turbulent fluctuations in the wind at right angles to the mean motion, and reported on his findings with this instrument in his Symons Memorial Lecture to the Royal Meteorological Society in 1927. Other workers have since made much use of this technique. In the 1930's, Sir Geoffrey gave new impetus to the study of turbulence in his now-famous series of papers on the statistical theory of isotropic turbulence. This work is very wide in scope and will find application in meteorology as it has already done in other fields of fluid-motion study. Sir Geoffrey has, of course, also made many outstanding contributions to other branches of physical science.

\section{Elliot Medal of the U.S. National Academy of Sciences: Prof. J. T. Patterson}

The Daniel Giraud Elliot Gold Medal of the United States National Academy of Sciences has been awarded to Prof. J. T. Patterson, director of zoological research in the University of Texas. The Elliot Medal is an annual award and is given for an outstanding paper on original research in zoology or palæontology. Prof. Patterson has made important contributions to genetics, particularly by his papers on isolating mechanisms which have been published in the volume entitled "Studies in the Genetics of Drosophila: V. Isolating Mechanisms", issued by the University of Texas in 1947. The studies reported in this volume mark the culmination of research in the phylogeny of Drosophila by genetical methods which Prof. Patterson initiated at the University of Texas more than twenty-five years ago. As a combination of experimental and taxonomic investigation it represents a highly significant contribution to research on the problem of species.

\section{Sir George Beilby Memorial Fund: Awards for 1950}

The administrators of the Sir George Beilby Memorial Fund, representing the Institute of Metals, the Royal Institute of Chemistry and the Society of Chemical Industry, have decided to make two awards for 1950, each of one hundred guineas, from the Fund. These awards have been made to W. A. Baker, in recognition of his experimental contributions to knowledge of the factors determining the production of sound castings of non-ferrous metals and alloys; and Dr. G. Whittingham, in recognition of his experimental contributions to knowledge of the combustion products of fuels containing sulphur and their effects on corrosion. Mr. Baker joined the staff of the Assay Office, Royal Mint, London, as a student assistant and graduated in metallurgy at the University of London as an external student in 1934. Shortly afterwards he joined the British NonFerrous Metals Research Association, where he was engaged mainly on such problems as the effects of volume changes and gas evolution in the solidification of metals and alloys, influence of alloy constitution and other metallurgical variables on the casting characteristics of the materials, and the general principles to be observed in developing foundry tech- 